\title{
Immunomodulatory action of propolis. Influence on anti-infectious protection and macrophage function
}

\author{
V Dimov $1^{*}, \mathrm{~N}$ Ivanovska ${ }^{1}, \mathrm{~N}$ Manolova 2, V Bankova ${ }^{3}$, \\ N Nikolov 4 , 5 Popov 3 \\ ${ }^{1}$ Bulgarian Academy of Sciences, Institute of Microbiology, \\ Department of Immunology, Sofia 1113; \\ 2 Bulgarian Academy of Sciences, Institute of Microbiology, Department of Virology; \\ ${ }^{3}$ Bulgarian Academy of Sciences; Institute of Organic Chemistry; \\ ${ }^{4}$ Chemico-Pharmaceutical Research Institute, Sofia, Bulgaria
}

(Received 7 May 1990; accepted 13 February 1991)

\begin{abstract}
Summary - The immunomodulatory action of a water-soluble derivative (WSD) of natural propolis was investigated. The oral and parenteral administration of the WSD enhanced the survival rate and the mean survival time in experimental bacterial (Klebsiella pneumoniae, Staphyllococcus aureus) and fungal (Candida albicans) infections in mice. An increased resistance was observed also in Klebsiella pneumoniae infection induced after cyclophosphamide treatment. The WSD stimulated peritoneal macrophages to produce in vitro interleukin-1, which corresponded to their elevated total protein secretion. In addition, WSD failed to trigger lymphocyte proliferation as determined by popliteal lymph node assay. The WSD was suggested to augment non-specific host defense via macrophage activation.
\end{abstract}

propolis / water-solubie derivative / immunomodulation / anti-infectious resistance / macrophage

\section{INTRODUCTION}

Honey bee products have been used in modern clinics, especially in the treatment of infections and allergle and inflammatory states (Pochinkova, 1986). Propolis is an effective remedy, exerting antiviral and antimicrobial activities (Manolova et al, 1985), Up to now, more than $100 \mathrm{com}-$ pounds, mainly polyphenols, have been identified as constituents of propolis col- lected in different regions. The major polyphenols are flavonoid aglycones, accompanied by phenolic acids and their esters, phenolic aldehydes, ketones, etc (Ghisalberti, 1979; Bankova and Marekov, 1984; Walker and Crane, 1987; Greenaway et al, 1989).

Anti-infectious drugs such as antibiotics or antivirals have begun to exhaust their therapeutic capabilities. The widespread occurrence of disfunctions of the immune

\footnotetext{
* Correspondence and reprints
} 
system requires new approaches. Immunomodulation through natural or synthetic substances may be considered an alternative for the prevention and cure of infectious diseases (Azuma and Jolles, 1987; Hadden et al, 1989; Toshkov et al, 1989). All known drugs and medicines based on natural propolis contain only its nonsoluble forms. Some of these oral preparations, like Aagard propolis (NF Borner, Germany), exert general biostimulation but their influence on the immune system has not been studied. A number of newly found propolis derivatives have been reported to inhibit viral replication in vitro and in vivo and to increase resistance against viral infections. These recently developed water-soluble fractions and forms of natural propolis can be applied both orally and parenterally, and having a better resorbtion, they are believed to possess an improved efficacy (Manolova et al, 1985, 1986; Maximova-Todorova et al, 1985; König and Dustmann, 1986).

The present study investigated the properties of one of the propolis forms, named water-soluble derivative (WSD), related to antibacterial and antifungal protection, and cellular mechanisms of action.

\section{MATERIALS AND METHODS}

\section{Water-soluble derivative (WSD) treatment}

The water-soluble derivative (WSD) was obtained according to the protocol of Nikolov et al (1987). Ten WSD specimens from different propolis samples collected in several geographical areas of Bulgaria were prepared. The differences between their chemical compositions were insignificant as detected by highperformance liquid chromatography (HPLC) and gas chromatography-mass spectrometry (GCMS) (Bankova et al, 1982, 1986; Bankova and Kuleva, 1989). Freeze-dried WSD was dissolved in distilled water at different concentrations and solutions were administered in various schemes (tables I-IV) to male and female inbred mice (ICR strain) 18-20 g bw.

\section{Experimental infections}

Bacterial and fungal infections in WSD- treated and nontreated (control) mice were induced with:

- Klebsiella pneumoniae, strain 52145 (Institute Pasteur, Paris) at a dose of 25-30 cells per mouse, sc;

Table I. Effect of WSD in experimental infections.

\begin{tabular}{|c|c|c|c|c|c|c|c|}
\hline \multirow[t]{2}{*}{$\begin{array}{c}\text { Treatment } \\
\text { Administration a }\end{array}$} & \multirow{2}{*}{ Dose ${ }^{\mathrm{b}}$} & \multicolumn{2}{|c|}{ KI pneumoniae } & \multicolumn{2}{|c|}{$\begin{array}{l}\text { Protection } \\
\mathrm{S} \text { aureus }\end{array}$} & \multicolumn{2}{|c|}{ C albicans } \\
\hline & & $\Delta S_{8}{ }^{c}$ & $\Delta M S T_{8}{ }^{\mathrm{d}}$ & $\Delta S_{15}$ & $\Delta M S T_{15}$ & $\Delta S_{30}$ & $\Delta M S T_{30}$ \\
\hline \multirow[t]{2}{*}{ po } & 150 & 16.0 & 0.7 & 8.6 & 0.1 & nd & nd \\
\hline & 50 & 50.0 & 1.9 & 11.4 & 1.2 & 62.5 & 10.3 \\
\hline \multirow[t]{2}{*}{ ip } & 150 & 60.0 & 2.2 & 16.2 & 1.2 & 55.6 & 17.0 \\
\hline & 50 & 11.0 & 0.1 & 12.8 & 0.9 & nd & nd \\
\hline \multirow[t]{2}{*}{ sc } & 150 & 14.0 & 0.6 & 11.4 & 1.9 & 25.0 & 4.4 \\
\hline & 50 & 10.0 & 0.1 & 1.4 & 0.6 & nd & nd \\
\hline
\end{tabular}

a Administered via different routes on 3 consecutive $d(-3,-2,-1)$ prior to inoculation. ${ }^{b}$ In $\mathrm{mg} / \mathrm{kg} .{ }^{c}$ Increase in survival rate (\%). ${ }^{d}$ Increase in mean survival time (d). nd, Not done. 
- Staphylococcus aureus, strain Smith (Institute of Microbiology, Sofia) at a dose of $2 \times 10^{9}$ cells per mouse, iv;

- Candida albicans, strain 562 (Institute of Infectious and Parasitic Diseases, Sofia) at a dose of $2 \times 10^{9}$ cells per mouse, iv.

Table II. Effect of WSD in experimental KI pneumoniae infection and immunosupression.

\begin{tabular}{|c|c|c|}
\hline \multirow[t]{2}{*}{ Treatment } & \multicolumn{2}{|c|}{ Protection } \\
\hline & $\Delta S_{8}{ }^{e}$ & $\Delta M S T_{8}{ }^{f}$ \\
\hline$W S D+C y a$ & +20.0 & +1.0 \\
\hline WSD b & +20.0 & +0.5 \\
\hline $\mathrm{Cy}(-1)^{\mathrm{c}}$ & -30.0 & -1.5 \\
\hline$C y(-20)^{d}$ & -6.7 & -0.6 \\
\hline
\end{tabular}

a Treated po with $50 \mathrm{mg} / \mathrm{kg}$ WSD and injected ip with $150 \mathrm{mg} / \mathrm{kg}$ Cy at $-3,-2,-1$ d prior to inoculation. b Treated only with WSD po as described. " Treated only with $C y$ as described. ${ }^{d}$ Treated with $C y$ in a dose and by a route as described at $-22,-21,-20 \mathrm{~d}$ prior to inoculation. ${ }^{e}$ Changes in survival rate (\%). ${ }^{1}$ Changes in mean survival time (d).
The doses for inoculation were chosen after preliminary experiments to achieve a survival rate of $\approx 30-40 \%$. The course of infections were followed up to the 8th, 15th and 30th d after inoculation with $K I$ pneumoniae, $S$ aureus and $C$ albicans, respectively. The survival rate (S) and mean survival time (MST) were calculated. The effect of WSD was expressed as a difference $(\Delta)$ in S or MST of WSD-treated and control groups.

\section{Immunosuppressive drug regimen}

The cyclophosphamide, Cy (Germed, Germany), was injected at different intervals prior to inoculation with $K I$ pneumoniae as described (see footnotes to table II).

\section{Macrophage cultures}

At the 5th, 7th, 15th and 20th d after treatment with WSD, peritoneal macrophages were obtained by a single washing of peritoneal cavity with $10 \mathrm{ml}$ of tissue medium RPMI 1640 supplemented with $20 \mathrm{mM}$ HEPES, $100 \mu \mathrm{g} / \mathrm{ml}$ streptomycin and $100 \mathrm{U} / \mathrm{ml}$ penicillin (Flow Lab, UK).

Table III. In vitro IL-1 activity and total protein secretion.

\begin{tabular}{|c|c|c|c|c|}
\hline Intervals a & \multicolumn{2}{|c|}{ IL-1 activity ${ }^{\mathrm{b}}$} & \multicolumn{2}{|c|}{ Total proteins $^{c}$} \\
\hline $\begin{array}{r}5 \\
7 \\
15 \\
20\end{array}$ & $\begin{array}{r}5264 \pm 642 \\
5793 \pm 768 \\
5922 \pm 482 \\
20429 \pm 1768 \\
5065 \pm 335 \mathrm{e} \\
1428 \pm 297^{\dagger} \\
1892 \pm 435 \mathrm{~g} \\
949 \pm 307 \mathrm{~h}\end{array}$ & $\begin{array}{l}(1.03)^{\mathrm{d}} \\
(1.14) \\
(1.17) \\
(4.03)\end{array}$ & $\begin{array}{l}6879 \pm 520 \\
6625 \pm 125 \\
8312 \pm 340 \\
8155 \pm 268 \\
5605 \pm 204\end{array}$ & $\begin{array}{l}(1.23)^{d} \\
(1.18) \\
(1.48) \\
(1.45)\end{array}$ \\
\hline
\end{tabular}

\footnotetext{
a Days after the last treatment with WSD (po; $50 \mathrm{mg} / \mathrm{kg}$ on 3 consecutive days) when macrophage were collected. ${ }^{b}$ Incorporation of ${ }^{3} \mathrm{H}$-thymidine by thymocytes expressed as mean counts per min $\pm \mathrm{SE}$ of triplicate wells in each group. ${ }^{\mathrm{c}}$ Secretion of ${ }^{14} \mathrm{C}$-glycine labeled proteins, presented as means counts per $\min \pm \mathrm{SE}$. d Values in parenthe-

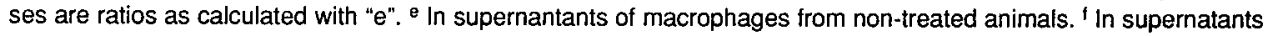
of macrophages from non-treated animals in the absence of PHA. 9 In supernatants of macrophages from treated animals in the absence of PHA. ${ }^{\mathrm{h}}$ Medium control.
} 
Table IV. PLN reaction to WSD.

\begin{tabular}{cccccccccc}
\hline Intervals a & 5 & 6 & 7 & 8 & 12 & 13 & 14 & 15 & Contro/c \\
\hline PLN index ${ }^{\mathrm{b}}$ & $\begin{array}{c}1.17 \\
\pm 0.25\end{array}$ & $\begin{array}{c}1.13 \\
\pm 0.58\end{array}$ & $\begin{array}{c}1.60 \\
\pm 0.46\end{array}$ & $\begin{array}{c}1.18 \\
\pm 0.29\end{array}$ & $\begin{array}{c}0.92 \\
\pm 0.40\end{array}$ & $\begin{array}{c}1.03 \\
\pm 0.32\end{array}$ & $\begin{array}{c}1.00 \\
\pm 0.38\end{array}$ & $\begin{array}{c}1.26 \\
\pm 0.33\end{array}$ & $\begin{array}{c}1.00 \\
\pm 0.01\end{array}$ \\
\hline
\end{tabular}

a Days after the injection with WSD $\left(3 \mathrm{mg} / 0.05 \mathrm{ml}\right.$ saline). ${ }^{b}$ Values are expressed as mean of 6 animals $\pm \mathrm{SE}$. $c$ Treated with $0.05 \mathrm{ml}$ saline only.

Cell suspensions in concentration of $2 \times 106 / \mathrm{ml}$ were plated on $16-\mathrm{mm}$ diameter wells (Nunc, Denmark).

\section{IL-1 activity assay}

The level of IL-1 in the 24-h macrophage supernatants was determined by augmentation of ${ }^{3} \mathrm{H}$-thymidine incorporation by mouse thymocytes (Meltzer and Oppenheim, 1977). Briefly, single cell suspensions of thymuses from ICR mice $\left(1.0 \times 10^{6}\right.$ cells in $\left.0.1 \mathrm{ml}\right)$ were cultured with $0.1 \mathrm{ml}$ of the macrophage supernatants at 1:4 dilution for $40 \mathrm{~h}$ in a 96-well microtissue culture plate. The culture medium contained a submitogenic concentration $(1 \mu \mathrm{g} / \mathrm{ml})$ of phytohaemagglutinin, PHA (Sigma, USA) and $2.5 \times 10^{-5}$ M 2-mercaptoethanol (Merck, Germany). Thymic cultures were pulsed for $6 \mathrm{~h}$ with $1 \mu \mathrm{Ci}$ of ${ }^{3} \mathrm{H}$ thymidine (Amersham, UK).

\section{Total protein secretion measurement}

A portion of macrophages was cultured in the presence of $1 \mu \mathrm{Ci} / \mathrm{ml}^{14} \mathrm{C}$-glycine (Amersham). After $24 \mathrm{~h}$ the radiolabelled proteins were counted.

\section{Popliteal lymph node (PLN) assay}

A single dose of WSD was injected into the right hind footpad leaving the contralateral side unin- jected as a control, according to the method of Gleichmann (1981). The popliteal lymph nodes were removed at different intervals and weighed immediately. The effect of WSD to ensure PLN reaction was expressed as PLN index being the ratio of the lymph node weights of the injected over the uninjected side.

\section{RESULTS AND DISCUSSION}

The pretreatment with WSD induced protection against the model infection, although the pathogens challenged different processes: lethal pneumonia, toxic septicemia, disseminated mycosis after $K I$ pneumoniae, $S$ aureus and $C$ albicans, respectively (table I). Better protective effect of the preparation emerged in the case of $K I$ pneumoniae infection as compared to another bacterial infection. The mortality rate in the course of $C$ albicans infection was relatively low. Previous data and present investigation suggest that propolis stimulates macrophages and enhances survival, because the macrophages are assumed to be the major factor preventing bacterial and fungal dissemination (Dimov et al, 1988).

In addition to its immunostimulatory action in the case of infections induced in intact hosts, WSD showed an immunorestorative effect. Profound immunosupression 
developed as a result of cyclophosphamide injections (table II). The infection in the immunocompromised host was strongly exacerbated as illustrated by negative $\Delta \mathrm{S}_{8}$ and $\Delta \mathrm{MST}_{8}$. Simultaneous administration of WSD prevented drug-induced immunosuppression and improved survival.

Based on the antibacterial and antifungal effect of WSD, and the anti-influenzal action of some propolis fractions (Manolova et al, 1985, 1986; Maximova-Todorova et al, 1985) we conclude that different propolis derivatives induce anti-infectious protection comparable to other immunostimulants (Azuma and Jolles, 1987; Hadden et al, 1988; Toshkov et al, 1989). The influence of some propolis fractions on specific and non-specific immune defense mechanisms, ie, the release of migration inhibitory factor, macrophage phagocytosis, numbers of rosette-forming and antibodyproducing cells, has been previously reported (Manolova et al, 1987; Neychev et al, 1988).

Since macrophages are required to provide anti-infectious defense, the influence of WSD on their function was established. The substance was found to stimulate macrophages to produce IL-1, which corresponded to enhanced protein secretion and was taken as a reference for macrophage activation (table III). The WSD slowly and continuously elevated the IL-1 production during the entire observation period. These long-lasting consequences of WSD application coincided with the antiinfectious protection up to the 30th day. The peak of the IL-1 activity at the 20th day was similar to the effect of the other immunostimulants on macrophage activation (Toshkov et al, 1989), and a connection with the metabolism of the agent should be investigated. A variety of immunostimulants, eg Lentinan (Yamanouchi Pharmaceutical Co, Japan), lipopolysaccharides, Broncho-Vaxom (Laboratories
OM, Switzerland), chitin derivatives, and muramil dipeptide have been examined as potent in vivo or in vitro inducers of IL-1 in man and animals (Chihara, 1984; Kido et al, 1984; Martin du Pan and Koechli, 1984; Nishimura et al, 1986; Oppenheim et al, 1980). Their proven therapeutic capability is related to action on macrophages. In the case of infections and neoplasms, this action includes changes in IL-1 (a lymphocyte activating factor), which is highly involved in immune cell cooperation.

Additional evidence that the action of WSD may be limited mainly to macrophages was shown in the lack of influence on lymphocyte proliferation. The injection of WSD failed to trigger a significant reaction, as illustrated by kinetics of popliteal lymph node enlargement (table IV). According to the detailed study of Gleichmann (1981), T cells are believed to be required for genuine PLN reactions. In contrast to previous observations on the effect of some propolis fractions on antigen-binding cells (Neychev et al, 1988), PLN non-responsiveness to the various WSD doses argues against the possibility that the agent acts as a mitogen on lymphocytes. The present experiments also suggest that WSD is incapable of inducing sensitization, thus mediating a proper effect through macrophages. The effect of similar propolis preparations on B lymphocytes is shown by augmentation of the number of plaque-forming cells and spleen weight index (Dimov et al, 1988; Scheller et al, 1988).

Based on the results presented here, we postulate that the broad therapeutic spectrum of propolis includes a pronounced immunomodulatory activity directed mainly toward augmenting non-specific anti-infectious resistance via macrophage activation. The exact mechanisms underlying the induced protection remain obscure. 
Résumé - Action immunomodulatrice de la propolis. Influence sur la protection anti-infectieuse et la fontion macrophage. Ce travail étudie l'action de dérivés hydrosolubles (WSD) de la propolis sur la défense de l'organisme contre l'infection et les réactions immunes. Des solutions à diverses concentrations de WSD lyophylisés de propolis ont été préparées stérilement. Elles ont été administrées par voie orale ou par injections intrapéritonales ou souscutanées à des souris consanguines (souche ICR), à des doses allant de 50 à 150 $\mathrm{mg}$ par $\mathrm{kg}$, durant $3 \mathrm{j}$ consécutifs avant l'inoculation de bactéries (Klebsiella pneumoniae et Staphylococcus aureus) ou de champignon (Candida albicans). On a calculé le taux de survie (S) et le temps moyen de survie (MST) à la fin du développement des infections modèles $(8,15$ ou $30 \mathrm{j}$ respectivement). L'action des WSD a été estimée d'après les différences $(\Delta)$ du $S(\%)$ et du MST (j) entre des souris traitées aux WSD et des souris non traitées (témoins). En général, le prétraitement aux WSD a suscité une protection maximale meilleure (tableau I) dans le cas de l'infection par Kl pneumoniae (+ 60,0\%; $+1,2 \mathrm{j})$. L'effet bénéfique des WSD a été également élevé dans le cas de l'infection fongique $(+62,5 \% ;+17,0 \mathrm{j})$. En outre, la substance a restauré la réponse immunitaire dans le cas de l'infection par KI pneumoniae chez des organismes hôtes immunodéprimés par application de cyclophosphamide (tableau II).

Les WSD ont stimulé la production in vitro d'interleukine-1 (IL-1) par les macrophages péritonéaux. Cette production, exprimée en coups/min par l'incorporation de ${ }^{3} \mathrm{H}$-thymidine par les thymocytes, a été maximale le $20^{\mathrm{e}} \mathrm{j}$ et correspond à la sécrétion accrue de protéines totales (tableau III).

L'injection de WSD, à la dose de $3 \mathrm{mg}$ dans la patte arrière droite, n'a pas réussi à déclencher la prolifération des lymphocytes des ganglions poplités (tableau IV). Ceci peut être considéré comme une preuve supplémentaire que l'action des WSD est limitée principalement aux macrophages. Il est évident que la propolis et ses dérivés présentent une activité immunomodulatrice marquée, qui se traduit par un augmentation de la résistance non spécifique due à l'activation des macrophages.

\section{propolis / dérivé hydrosoluble I immunomodulation / résistance anti- infectieuse / macrophage}

Zusammenfassug - Wirkung von Pro-
polis auf die Immunomodulation. Ein-
fluß auf den Schutz vor Infektion und
die Funktion der Makrophagen. Lösungen verschiedener Konzentrationen von gefriergetrockneten wasserlöslichen Auszügen (WSD) von Propolis wurden unter sterilen Bedingungen zubereitet. Sie wurden entweder oral oder durch intraperitoneale bzw subkutane Injektion ingezüchteten Mäusen (Stamm ICR) in Dosen von 50 bis $150 \mathrm{mg}$ per $\mathrm{kg}$ verabreicht. Diese Behandlung wurde an drei aufeinanderfolgenden Tagen durchgeführt, bevor eine Impfung mit Bakterien (Klebsiella pneumoniae und Staphylococcus aureus) oder Pilzen (Candida albicans) erfolgte. Am Ende des vorgeplanten Experiments (nach 8, 15 und 30 Tagen) wurden Überlebensrate (S) und mittlere Überlebenszeit (MST) berechnet. Der Effekt von WSD wurde geschätzt aus den Unterschieden $(\Delta)$ bei $S$ (\%) und MST (Tagen) zwischen WSDbehandelten und Kontroll- (unbehandelten) Gruppen. Im allgemeinen führte die Vorbehandlung mit WSD bei einer Klebsiella pneumoniae-Infektion zu einem besseren Schutz (Tab I): $+60.0 \%$ und +1.2 Tage. Auch bei einer Pilzinfektion war die günstige Wirkung hoch $+62.5 \%$ und +17 
Tage). Die Substanz regenerierte außerdem das Immunsystem während einer Infektion mit Klebsiella pneumoniae bei Wirtstieren, die vorher durch Cyclophosphamide immungeschädigt worden waren (Tab II).

Das WSD regte die peritonealen Makrophagen an, in vitro interleukin-1 (IL-1) zu produzieren, mit einem Maximum am 20 Tag und ausgedrückt durch den Mittelwert pro min des von den Thymozyten aufgenommenen ${ }^{3} \mathrm{H}$-Thymidin, was der erhöhten Abscheidung an Gesamtproteinen entspricht (Tab III).

Die Injektion von WSD ( $3 \mathrm{mg}$ in den Ballen der rechten Hinterpfote) führte zu keiner Vermehrung der Lymphozyten wie aus einer Überprüfung der poplitealen Lymphknoten hervorgeht (Tab IV). Dies kann als weiterer Hinweis darauf gelten, daß die Wirkung von WSD vorwiegend auf die Makrophagen beschränkt ist. Es ist offensichtlich, daß Propolis und seine Bestandteile eine ausgesprochene immunregulatorische Aktivität entfalten, ausgeübt durch eine Stärkung einer unspezifischen Resistenz über die Aktivierung von Makrophagen.

\section{Propolis / wasserlöslicher Auszug / Im- munomodulation / antiinfektische Resi- stenz / Makrophage}

\section{REFERENCES}

Azuma I, Jolles G (eds) (1987) Immunostimulants. Now and Tomorrow. Proc FrenchJapan Joint Conference on Immunomodulators, Paris, 1986. Springer-Verlag, Berlin

Bankova V, Marekov N (1984) Propolischemical composition and standardisation. Farmazia 34, 8-18 (in Bulgarian)

Bankova V, Kuleva L (1989) Phenolic compounds of propolis from different regions of Bulgaria. Zivo Nauki 2, 94-98 (in Bulgarian)
Bankova V, Popov S, Marekov N (1982) HPLC analysis of flavonoids from propolis. $J$ Chromatogr 242, 135-143

Bankova V, Dyulgerov A, Popov S, Marekov N (1986) A GC-MS study of the propolis phenolic constituents. $Z$ Naturforsch $42 c, 147-$ 151

Bankova V, Popov S, Marekov N, Manolova N, Maximova V, Gegova G, Serkedjieva Y, Uzunov $S$ (1988) On the chemical composition of some propolis fractions with antiviral action. Acta Microbiol Bulg 23, 52-57 (in Bulgarian)

Chihara G (1984) Immunopharmacology of lentinan and glucans. EOS-Riv Immunol Immunopharmacol 4, 85-96

Dimov V, Neychev H, Slavcheva E, Shirova L, Vuleva V, Manolova N, Gegova G (1988) Effect of "TR fraction" on experimental infection with KI pneumoniae. In: Abstracts of 2 nd Symposium on Current Problems in Testing and Evaluation of Experimental and Clinical Effects of Immunomodulators. CSFR, Kosice, 6-7

Ghisalberti E (1979) Propolis: a review. Bee World 60, 59-84

Gleichmann H (1981) Studies on the mechanism of drug sensitization: T-cell-dependent popliteal lymph node reaction to diphenylhydantoin. Clin Immunol Immunopathol 18, 203-211

Greenaway W, Scaysbrook T, Whatley F (1989) The analysis of bud exudate of Populus euramericana, and of propolis, by GC-MS. Proc $R$ Soc Lond B232, 249-272

Hadden JW, Spreafico F, Yamamura $Y$, Austen KF, Dukor P, Masek K (eds) (1989) $A d$ vances in Immunopharmacology 4. Proc IVth Int Conf Immunopharmacology, 1988, Osaka. Pergamon Press, Oxford

Kido N, Nekeshima I, Kato N (1984) Correlation between strong adjuvanticity of Klebsiella 03 lipopolysaccharide and its ability to induce interleukin secretion. Cell Immunol 85, 477-486

König B, Dustmann H (1986) Propolis und Viren: der Gegenwärtige Forschungsstand. Apidologie 17, 334-336

Manolova N, Maximova V, Gegova G, Serkedjieva $Y$, Uzunov $S$, Marekov $N$, Bankova $V$ (1985) On the anti-influenza action of fractions from propolis. CR Acad Bulg Sci 38, 735-737 
Manolova N, Korczak E, Denis A, Maximova V, Serkedjieva Y, Gegova G, Uzunov S, Marekov N, Bankova V, Popov S (1986) Effect of fractions of the natural product " $P$ " on the infectious processes in mice infected with influenza A virus. In: Proceedings of the 6 th Congress of Bulgarian Microbiologists, Varna, 13-15 October 1985 (Bardarov S et al, eds) Union of Scientific Workers in Bulgaria, Sofia, vol II, 46-50

Manolova N, Maximova V, Manolova Z, Stoilova I, Korczak E, Denis A (1987) Immunobiological effect of propolis. I. Effect on cellular immunity. Acta Microbiol Bulg 21, 76-81 (in Bulgarian)

Maximova-Todorova V, Manolova N, Gegova G, Serkedjieva $Y$, Uzunov S, Pancheva S, Marekov N, Bankova V (1985) Antiviral action of some fractions isolated from propolis. Acta Microbiol Bulg 17, 79-84 (in Bulgarian)

Martin du Pan RE, Koechli B (1984) InterferonInduktion durch das Bakterienlysat BronchoVaxom: eine klinische Doppelblindstudie fur das Kinderalter. Kinderarzt 15, 646-651

Meltzer MS, Oppenheim JJ (1977) Bidirectional amplification of macrophage-lymphocytes activation factor production by activated adherent mouse peritoneal cells. $J$ Immunol $118,77-82$

Neychev H, Dimov V, Vuleva V, Shirova L, Slavcheva E, Gegova G, Manolova N, Bankova
V (1988) Immunomodulatory action of propolis. II. Effect of water-soluble fraction on influenza infection in mice. Acta Microbiol Bulg 23, 58-62

Nikolov N, Marekov N, Bankova V, Popov S, ignatova R, Vladimirova I (1987) Method for the preparation of water-soluble derivative of propolis. Bul Pat Appl 79903/28, 05

Nishimura $\mathrm{K}$, Ischihara $\mathrm{CH}$, Ukei $\mathrm{S}$, Tokura $\mathrm{S}$, Azuma I (1986) Stimulation of cylokine production in mice using deacetylated chitin. Vaccine 4, 151-156

Oppenheim JJ, Togawa A, Chedid L, Mizel S (1980) Components of mycobacteria and muramyldipeptide with adjuvant activity induce lymphocyte activating factor. Cell Immunol 50, 71-81

Pochinkova P (1986) Bee Products in Medicine. Publ House of Bulgarian Academy of Sciences, Sofia (in Bulgarian)

Scheller S, Gazda G, Pietsz G, Gabrys J, Szumlas J, Eckert L, Shani J (1988) The ability of ethanol extract of propolis to stimulate plaque formation in immunized mouse spleen cells. Pharmacol Res Commun 20, 323-328

Toshkov A, Dimov V, Denchev V, Vassilev C (1989) Immunomodulators in Infectious Diseases. State Publishing House Medizina i Fiskultura, Sofia (in Bulgarian)

Walker $P$, Crane $E$ (1987) Constituents of propolis. Apidologie 18, 327-334 